prof. dr. sc. Boris Tušek

Ekonomski fakultet, Sveučilište u Zagrebu, Zagreb, Republika Hrvatska btusek@efzg.hr

doc. dr. sc. Ana Ježovita

Ekonomski fakultet, Sveučilište u Zagrebu, Zagreb, Republika Hrvatska ajezovita@efzg.hr

Petra Halar, mag. oec.

Ekonomski fakultet, Sveučilište u Zagrebu, Zagreb, Republika Hrvatska phalar@efzg.hr

\title{
IZAZOVI DJELOVANJA INTERNE I EKSTERNE REVIZIJE U ERI PANDEMIJE COVID-19
}

Primljen: 21. kolovoza 2020.

Prihvaćen: 2. prosinaca 2020.

https://doi.org/10.46458/27121097.2020.26.111

Pregledni rad

\section{Sažetak}

Kriza uzrokovana respiratornom bolešću COVID-19 promijenila je i iz temelja mijenja privatni i poslovni svijet, čemu u prilog govori činjenica da će se u budućnosti govoriti o svijetu 'prije' $i$ 'nakon' pandemije COVID-19. COVID-19 predstavlja disrupciju koja nepovratno mijenja interno i eksterno okruženje poduzeća, neovisno o njihovoj veličini, djelatnosti ili državi u kojoj posluju. Kao što je kroz povijest već nekoliko puta potvrđeno, u kriznim vremenima potvrđuje se važnost $i$ ističe nužnost postojanja učinkovitih i djelotvornih internih $i$ eksternih nadzornih mehanizama korporativnog upravljanja koji stvaraju razliku i doprinose uspješnosti poslovanja poduzeća, pri čemu upravo interna i eksterna revizija predstavljaju ključne mehanizme. Prema tome, suvremeno doba postavlja brojne nove izazove pred djelovanje interne i eksterne revizije, odnosno cjelokupne revizijske profesije koja mora sve više proaktivno djelovati predviđajući sve moguće scenarije utjecaja disruptivnih događaja na poslovanje poduzeća $i$ predlagati prilagođena rješenja za pojedinu situaciju. Utjecaj pandemije uzrokovane respiratornom bolešću COVID-19 na djelovanje interne i eksterne revizije je dvojak. S jedne strane, mijenja se poslovanje poduzeća koje predstavlja objekt 
revizijskih angažmana, dok se s druge strane, mijenja i sam način djelovanja interne i eksterne revizije. Da bi revizijska profesija stvarala dodanu vrijednost i unaprjeđivala poslovanje poduzeća pružanjem pravovremenih i proaktivnih revizijskih i nerevizijskih angažmana, primarno je važno da se interna i eksterna revizija prilagođavaju suvremenim uvjetima poslovanja i novim izazovima s kojima se susreću u svojem djelovanju. Pri tome se, u uvjetima 'revizije na daljinu' (engl. Remote Auditing), posebice ističe važnost integrirane revizije, odnosno zajedničke suradnje interne i eksterne revizije radi premošćivanja svih izazova $i$ nedostataka u radu bilo internih, bilo eksternih revizora, a sve radi osiguravanja sinergije djelovanja internog $i$ eksternog nadzornog mehanizma korporativnog upravljanja koje vodi opstanku poduzeća i stvaranju dodane vrijednosti njegovim interesno-utjecajnim skupinama u suvremenim izrazito neizvjesnim uvjetima poslovanja uzrokovanih pandemijom COVID-19.

Ovim radom nastoje se dati odgovori na sljedeća istraživačka pitanja: S kojim se sve izazovima susreće revizijska profesija u eri pandemije uzrokovane respiratornom bolešću COVID-19? Na koji način navedeni izazovi utječu na djelovanje interne i eksterne revizije? Kako interna i eksterna revizija trebaju odgovoriti na rastuće izazove da bi ispunile svoje svrhe postojanja? Da bi se odgovorilo na postavljena istraživačka pitanja, definirani su i ciljevi rada: 1) dati pregled utjecaja pandemije COVID-19 na djelovanje interne $i$ eksterne revizije, 2) analizirati $i$ predložiti moguće odgovore interne i eksterne revizije na rastuće izazove s kojima se susreću u svome djelovanju uslijed pandemije COVID-19, te 3) analizirati $i$ utvrditi mogućnosti zajedničke suradnje interne $i$ eksterne revizije radi povećanja njihove značajnosti kao nadzornih mehanizama korporativnog upravljanja u eri pandemije COVID-19. Radi ostvarivanja postavljenih ciljeva, provedena je analiza sekundarnih izvora podataka, pri čemu su primarno korištene znanstvene metode analize, sinteze, deskripcije, klasifikacije te komparacije.

Ključne riječi: interna revizija, eksterna revizija, COVID-19;

JEL: M41, M42 


\section{UVOD}

Suvremeno poslovanje poduzeća obilježava izloženost neizvjesnoj i kaotičnoj okolini, što od upravljačkih struktura zahtijeva proaktivnu prilagodbu poslovanja novonastalim nestabilnim uvjetima. Iako bi poslovno odlučivanje u što je moguće većoj mjeri trebalo biti racionalno, stohastičnost poslovanja pred menadžere stavlja brojne nepredvidive izazove kojima moraju upravljati kako bi izbjegli nepovoljne posljedice i usmjerili poslovanje poduzeća ostvarivanju strateških ciljeva. Recentni ekonomski, epidemiološki, politički, tehnološki, kulturološki i socijalni trendovi nerijetko rezultiraju neočekivanim inherentnim rizicima koji mogu imati neznačajne ili značajne efekte na poslovanje poduzeća, pa čak i dovesti u pitanje njihovu vremensku neograničenost poslovanja. Prva polovica 2020. godine obilježena je krizom globalnih razmjera koja je posljedica pandemije uzrokovane respiratornom bolešću COVID-19. Negativne posljedice 'zatvaranja svijeta' na više od dva mjeseca mjerit će se idućih mjeseci, a vjerojatno i godina. Rezultat krize je propadanje brojnih, do nedavno, uspješnih poduzeća za čijim proizvodima ili uslugama je potražnja jednostavno nestala ili su bili prisiljeni zatvoriti svoje trgovine i objekte zbog epidemiološke situacije. Poduzeća koja uslijed dostatne rezerve likvidnosti uspiju opstati na tržištu mogu očekivati značajno smanjenje profitabilnosti i pogoršanje financijskog položaja u nadolazećem razdoblju. Jasno je da se cjelokupna situacija ne može promatrati jednostrano te da postoje i ona poduzeća koja su ovu krizu iskoristila kao šansu. Da se ipak radi o manjem broju takvih poduzeća u prilog govore negativne posljedice pandemije koje su već sada vidljive u povećanoj nezaposlenosti, smanjenju BDP-a i povećanju deficita državnog proračuna.

Jasno je da rizike nije moguće u potpunosti izbjeći, posebice ako su njihovi razmjeri nepredvidivi kao što je slučaj s ovom pandemijom, ali je potrebno njima upravljati kako bi ih se svelo na najmanju moguću razinu. Isto tako, početno ignoriranje značajnih rizika poslovanja može rezultirati i težim posljedicama nego pravovremeno suočavanje s njima. U ovom razdoblju, menadžeri su suočeni s nemjerljivim izazovima i iskušenjima, kao i potencijalno pogrešnim odlukama koje mogu imati značajne efekte na opstanak poduzeća. Iako neke rizike i posljedice krize nije moguće anticipirati, sinergijsko djelovanje mehanizama korporativnog upravljanja u značajnoj mjeri može ublažiti efekte nepovoljnih događaja. Nadzorni mehanizmi korporativnog upravljanja, kao primjerice interna revizija, $u$ značajnoj mjeri mogu pomoći poduzeću u ostvarivanju postavljenih ciljeva uvodeći sustavan i discipliniran pristup procjenjivanju i poboljšanju djelotvornosti upravljanja rizicima. S druge strane, eksterni revizori svojim djelovanjem mogu različitim interesno-utjecajnim skupinama pružiti razumno uvjerenje i mišljenje o realnosti i objektivnosti financijskog položaja, uspješnosti poslovanja i novčanih tokova koje je relevantno u kontekstu ulaganja, stvaranja novih i održavanja 
postojećih poslovnih odnosa, financiranja poslovanja, ali i osiguravaju pouzdanih informacija upravljačkim strukturama poduzeća.

Brojni poslovi koje je donedavno bilo nezamislivo obavljati bez fizičkog kontakta u sve većoj mjeri se obavljaju radom na daljinu. Revizijska profesija u tom kontekstu nije iznimka te se suočava s neočekivanim izazovima koje donosi revizija na daljinu (engl. Remote Auditing). Pored činjenice da su revizori suočeni $\mathrm{s}$ iznenadno novim, donedavno nezamislivim, pristupom i ubrzanom digitalizacijom u obavljanju svojih aktivnosti, suočavaju se i s novim nenadanim i do sada nepoznatim inherentnim rizicima kojima se moraju baviti u okviru obavljanja angažmana. Više nego ikad prije u fokusu su mogući sinergijski efekti zajedničkog djelovanja internih i eksternih revizora u ispunjavanju njihovih odgovornosti i doprinosu očuvanja vrijednosti i osiguranja vremenske neograničenosti poslovanja poduzeća čime se stvara kvalitetna podloga značajnijeg razvoja integrirane revizije.

Iz navedenog problema istraživanja proizlaze sljedeća istraživačka pitanja: $\mathrm{S}$ kojim se sve izazovima susreće revizijska profesija u eri pandemije uzrokovane respiratornom bolešću COVID-19? Na koji način navedeni izazovi utječu na djelovanje interne i eksterne revizije? Kako interna i eksterna revizija trebaju odgovoriti na rastuće izazove da bi ispunile svoje svrhe postojanja? Da bi se odgovorilo na postavljena istraživačka pitanja, definirani su i ciljevi rada: 1) dati pregled utjecaja pandemije COVID-19 na djelovanje interne i eksterne revizije, 2) analizirati i predložiti moguće odgovore interne i eksterne revizije na rastuće izazove s kojima se susreću u svome djelovanju uslijed pandemije COVID-19, te 3) analizirati i utvrditi mogućnosti zajedničke suradnje interne i eksterne revizije radi povećanja njihove značajnosti kao nadzornih mehanizama korporativnog upravljanja u eri pandemije COVID-19.

\section{IZAZOVI INTERNE REVIZIJE U RAZDOBLJU PANDEMIJE COVID-19}

Interna revizija se može definirati kao „neovisno i objektivno pružanje angažmana s izražavanjem uvjerenja i savjetodavnih usluga, osmišljena da doprinosi stvaranju dodane vrijednosti i unapređuje poslovanje organizacije. Ona pomaže organizaciji $\mathrm{u}$ ispunjavanju njezinih ciljeva uvodeći sustavan, discipliniran pristup procjenjivanju i poboljšanju djelotvornosti upravljanja rizicima, kontrole i korporativnog upravljanja“" (Hrvatski institut internih revizora, 2017., 17). Interna revizija, kao ključan interni nadzorni mehanizam korporativnog upravljanja, predstavlja nadzornu i savjetodavnu funkciju čiji objekt ispitivanja predstavlja cjelokupno poslovanje poduzeća okrenuto budućnosti, kao i anticipirani rizici 
(Tušek, et al., 2014., 27). Interni revizori, kao zaposlenici poduzeća koje predstavlja objekt ispitivanja, pružaju nekoliko vrsta angažmana, i to: angažmane s izražavanjem uvjerenja, savjetodavne angažmane i angažmane uvida (Hrvatski institut internih revizora, 2017., 9).

Izrazito neizvjesni i nestabilni uvjeti poslovanja uzrokovani pandemijom COVID-19 te, posljedično, uvođenje restriktivnih epidemioloških mjera, a posebice nametanje nužnosti socijalnog distanciranja, ne predstavljaju 'uobičajeni način' poslovanja poduzeća (engl. Business as Usual) (PEMPAL IACOP, 2020., 8), kao niti djelovanja funkcija interne revizije. Glavni interni revizori moraju vrlo pažljivo razmotriti koje aktivnosti, i na koji način trebaju obavljati, kako bi stvorili dodanu vrijednost i pomogli poduzeću u ostvarivanju postavljenih ciljeva u kriznom vremenu obilježenom ograničenim međuljudskim kontaktima (AuditBoard, 2020; PEMPAL IACOP, 2020.). Upravo u kriznim vremenima, poput krize uzrokovane pandemijom COVID-19, djelovanje funkcije interne revizije, kao treće linije obrane za učinkoviti proces upravljanja rizicima i kontrole, je ključno. Pojavljuju se brojni novi rizici, a postojeće interne kontrole, kao instrument upravljanja rizicima, se u većini slučaja ne prilagođavaju dovoljno brzo novim uvjetima, odnosno novim vrstama rizika što može stvoriti negativne posljedice za poslovanje poduzeća. Upravo zbog toga glavni interni revizori trebaju biti dio timova za upravljanje krizama u poduzećima, kako bi kao objektivni, kritični i savjetodavni partneri upravljačkih struktura mogli davati relevantne i pouzdane informacije, kao i savjete o rizicima, koje upravljačke strukture trebaju uzeti u obzir prilikom upravljanja poslovanjem poduzeća (KPMG, 2020 b b, 1; PEMPAL IACOP, 2020., 9; The Institute of Internal Auditors Global, 2020., 2). Funkcije interne revizije se trebaju fokusirati na ključne rizike, koji su uzrokovani pandemijom COVID-19, a povezani su sa sljedećim područjima poslovanja poduzeća, i to sa: telekomunikacijama, ljudima, operativnim poslovanjem, lancem opskrbe i eksternalizacijom usluga, financijskim upravljanjem, tehnologijama, te cyber sigurnošću (AuditBoard, 2020., 4-5; KPMG, 2020. b, 2; PEMPAL IACOP, 2020., 11-13). Drugim riječima, funkcije interne revizije trebaju pružiti savjetodavnu potporu poduzećima, provođenjem analize utjecaja pandemije COVID-19 na poslovanje poduzeća, fokusirajući se pritom posebice na ljude, procese i tehnologiju (AuditBoard, 2020., 4). Uz rizike, interni revizori se trebaju fokusirati i na povezane interne kontrole koje trebaju minimizirati navedene rizike (PEMPAL IACOP, 2020., 10-11). Iako većina poduzeća ima uspostavljene planove oporavka od katastrofa i kontinuiteta poslovanja (engl. Disaster Recovery and Business Continuity Plans), niti jedan plan nije mogao predvidjeti situaciju poput krize uzrokovane pandemijom COVID-19, jer u ovome slučaju nije nedostupna infrastruktura, nego ljudi, kao ključni resursi, koji su u izrazito kratkom roku, nepripremljeni, morali prijeći na online način rada, odnosno početi 'raditi na daljinu' (engl. Gone Remote, Remote Working) (AuditBoard, 2020., 3; KPMG, 2020. b, 2). 
Strategije stabilnosti, defenzivne strategije ili strategije opstanka koje su prisutne u brojnim poduzećima u kriznim vremenima, od funkcija interne revizije zahtijevaju pružanje proaktivnih savjetodavnih angažmana i angažmana uvida (Tušek, et al., 2018., 265; KPMG, 2020. b, 1; PEMPAL IACOP, 2020., 8; The Institute of Internal Auditors Global, 2020., 3). Pri tome, funkcije interne revizije će i dalje trebati pružati obvezujuće angažmane s izražavanjem uvjerenja, i to prvenstveno zahvaljujući informacijskim tehnologijama (PEMPAL IACOP, 2020., 9), odnosno ,objektivan pregled dokaza u svrhu pružanja neovisnog vrednovanja korporativnog upravljanja, upravljanja rizicima te kontrolnih procesa organizacije“" (Hrvatski institut internih revizora, 2017., 236), poput financijskih i operativnih revizija, revizija usklađenosti, revizija sigurnosti sustava te dubinskih snimanja (Hrvatski institut internih revizora, 2017., 236). No, interni revizori će pridonijeti poboljšanju poslovanja poduzeća, u suvremenim uvjetima poslovanja, upravo pružanjem rezultata različitih vrsta savjetodavnih angažmana, poput savjetovanja, preporuka, usmjeravanja i edukacija, kojima je i cilj stvoriti dodanu vrijednost $\mathrm{i}$ unaprijediti proces korporativnog upravljanja, proces upravljanja rizicima te sustav internih kontrola (Hrvatski institut internih revizora, 2017., 237). Uz savjetodavne angažmane, ključni angažmani interne revizije, u COVID-19 vremenima, postaju i angažmani uvida, koji se nazivaju još i 'izvanredna revizija', 'ad hoc revizija' ili 'revizija na zahtjev'. Navedeni angažmani interne revizije ne rezultiraju nužno mišljenjima i preporukama, već očitovanjima o utvrđenim činjenicama koje upravljačkim strukturama pružaju pomoć u donošenju konkretnih odluka, odnosno bez izražavanja konkretnih mišljenja i zaključaka te bez davanja preporuka internih revizora za poboljšanje (Tušek, 2017., 31). „Upravljačke strukture poduzeća od internih revizora očekuju upravo te vrste angažmana jer zahtijevaju da im funkcija interne revizije bude podrška i pomoć u generiranju informacija i podloga za donošenje poslovnih odluka u uvjetima ograničenih resursa“" (Tušek, et al., 2018., 265). Da bi funkcije interne revizije mogle ispunjavati nove uloge koje od njih zahtijevaju upravljačke strukture, važno je da interni revizori imaju odgovarajuće kompetencije za pružanje visokovrijednih savjeta i uvida, te na raspolaganju odgovarajuće alate i tehnologiju za obavljanje angažmana interne revizije (KPMG, 2020. b, 2; PEMPAL IACOP, 2020., 10). Funkcije interne revizije trebaju biti fleksibilne, agilne i proaktivne, ali pritom interni revizori ne trebaju 'igrati' uloge heroja, kao što se ne smije dogoditi da menadžeri postavljaju pitanja, poput gdje su bili i što su radili interni revizori tijekom pandemije (PEMPAL IACOP, 2020., 10).

Vrlo je važno da se, kako unutar poduzeća, tako i unutar funkcija interne revizije, poduzmu odgovarajući koraci i aktivnosti u sadašnjosti, kao i naprave odgovarajući planovi aktivnosti za budućnost kao odgovor na posljedice krize uzrokovane pandemijom COVID-19. Pritom je ključno odgovarajuće vodstvo i upravljanje poduzećem, odnosno funkcijom interne revizije (KPMG, 2020. a, 1). Uz to, vrlo 
je važno osigurati pravovremenu i jasnu komunikaciju sa zaposlenicima te poštivati sve organizacijske smjernice, kao i smjernice javnozdravstvenih organizacija kako bi se zaštitili od svih rizika koje uzrokuje respiratorna bolest COVID-19 (KPMG, 2020. a, 1). Potrebno je pregledati i ažurirati ili donijeti nove planove oporavka od katastrofa i kontinuiteta poslovanja, kako na razini poduzeća, tako i na razini funkcije interne revizije (KPMG, 2020. a, 1). Pritom, funkcija interne revizije pravodobnim isporučivanjem rezultata savjetodavnih angažmana $i$ angažmana uvida treba biti pomoć i podrška upravljačkim strukturama prilikom ažuriranja planova oporavka od katastrofa i kontinuiteta poslovanja. Uz sve navedeno, važno je da se funkcije interne revizije prilagode novoj situaciji, te da ažuriraju dugoročne i kratkoročne planove interne revizije, kako bi se fokusirale na nove prioritete koje nameće pandemija COVID-19. Prilagođavanje, fleksibilnost, proaktivnost, pravodobnost, kompetentnost i agilnost su obilježja koja su nužnost za učinkovito djelovanje sve tri linije obrane za učinkoviti proces upravljanja rizicima i kontrole, a posebice funkcija interne revizije, uslijed neizvjesnih uvjeta poslovanja i rada na daljinu (AuditBoard, 2020.; KPMG, 2020. a; KPMG, 2020. b; PEMPAL IACOP, 2020.; The IIA's Audit Executive Center, 2020.).

Pandemija COVID-19, uz trenutne učinke, imat će i dalekosežne posljedice, kako na poslovanje poduzeća, tako i na djelovanje funkcija interne revizije. Upravo zbog toga The IIA's Audit Executive Center (2020., 1) je proveo istraživanje o percepcijama dugoročnih učinaka pandemije COVID-19 na djelovanje funkcija interne revizije od strane glavnih internih revizora. Istraživanje je provedeno u razdoblju od 3. do 5. lipnja 2020. godine, pri čemu je sudjelovalo ukupno 486 glavnih internih revizora i rukovoditelja interne revizije iz Sjedinjenih Američkih Država ( $87 \%$ ispitanika) i Kanade (13 \% ispitanika) (The IIA's Audit Executive Center, 2020., 1). Rezultati istraživanja su pokazali kako glavni interni revizori smatraju da su ključna područja djelovanja internih revizora, na koja će novonastala situacija uzrokovana pandemijom COVID-19 imati dugoročne učinke, odnosno posljedice, bilo negativne, bilo pozitivne:

- budžeti funkcija interne revizije

- učestalost procjenjivanja rizika i ažuriranja planova interne revizije

- učestalost komunikacija s revizijskim odborom

- povećanja potražnja za određenim kompetencijama (The IIA’s Audit Executive Center, 2020., 1).

Gotovo polovica glavnih internih revizora (44 \% od ukupno 482 ispitanika koji su odgovorili na pitanje) očekuje da će se budžeti funkcija interne revizije smanjiti tijekom idućih 12 mjeseci, usprkos pojavi novih rizika uslijed pandemije (The IIA's Audit Executive Center, 2020., 4). Pri tome, od sve četiri istraživane 
komponente budžeta funkcija interne revizije, izdataka za putovanja, izdataka za članove funkcija interne revizije, izdataka za revizijske usluge pružene od trećih strana te izdataka za profesionalni razvoj internih revizora, komponenta izdataka za putovanja je ocijenjena kao komponenta budžeta za koju glavni interni revizori očekuju da će se budžet najviše smanjiti ( 87 \% ispitanika od ukupno 482 ispitanika koji su odgovorili na pitanje) (The IIA's Audit Executive Center, 2020., 4). Što se tiče učestalosti procjenjivanja rizika i ažuriranja planova interne revizije, rezultati istraživanja su pokazali kako $53 \%$ od ukupno 485 glavnih internih revizora očekuju učestalije procjene rizika, dok $68 \%$ od ukupno 485 glavnih internih revizora očekuju učestalija ažuriranja planova interne revizije uslijed pandemije COVID-19 (The IIA's Audit Executive Center, 2020., 10-12). Usprkos povećanju učestalosti procjenjivanja rizika i ažuriranja planova interne revizije, većina glavnih internih revizora ipak očekuje da će učestalost komunikacije s revizijskim odborom ostati na istoj razini (63 \% od ukupno 481 ispitanika koji su odgovorili na pitanje) (The IIA's Audit Executive Center, 2020., 13). Uz prethodno anticipirane promjene, također jedna od značajnih promjena je i promjena načina obavljanja angažmana interne revizije, odnosno drugim riječima, promjena načina djelovanja internih revizora. „Od početka globalne pandemije, većina internih revizora je primarno djelovala od kuće (engl. Working From Home)“ (The IIA's Audit Executive Center, 2020., 14). Kao posljedica značajnog smanjenja budžeta za putovanja internih revizora, kao i smanjenja produktivnosti poslovanja poduzeća, ali i povezanih zdravstvenih rizika koje uzrokuje respiratorna bolest COVID-19, i dalje se očekuje da će interni revizori više djelovati od kuće (The IIA's Audit Executive Center, 2020., 14). Stoga, ključne promjene koje glavni interni revizori očekuju vezano uz način obavljanja procesa interne revizije su:

- povećanje upotrebe postupaka analize podataka (engl. Data Analytics)

- povećanje upotrebe tehnika agilne interne revizije (engl. Agile Auditing Techniques)

- fokusiranje na pružanje savjetodavnih angažmana

- fokusiranje na identificiranje načina za uštedu troškova poduzeća

- smanjivanje vremena trajanja angažmana interne revizije

- povećanje upotrebe revizijskih softvera

- povećanje ulaganja u automatizaciju procesa interne revizije

- povećana upotreba robotske automatizacije procesa (engl. Robotic Process Automation) (The IIA's Audit Executive Center, 2020., 15).

Da bi interni revizori mogli što učinkovitije i djelotvornije obavljati angažmane interne revizije i stvarati dodanu vrijednost poduzeću, moraju posjedovati odgovarajuće kompetencije. Prema rezultatima istraživanja, najvažnije kompetencije, koje interni revizori u suvremenom dobu obilježenom pandemijom COVID-19 
trebaju posjedovati, su kombinacija tradicionalnih 'mekih' vještina, poput vještina komunikacije i sposobnosti inoviranja i promjena, kao i kompetencija povezanih s rastućim rizicima, poput rizika cyber sigurnosti, zdravstvenih i sigurnosnih rizika, kao i rizika prijevara (The IIA's Audit Executive Center, 2020., 20). Stručnost $u$ analizi podataka je i dalje visokotražena kompetencija internih revizora (The IIA's Audit Executive Center, 2020., 20).

Uzevši u obzir sve prethodno navedeno, ključni izazovi s kojima se interni revizori susreću prilikom obavljanja revizijskih i nerevizijskih angažmana uslijed krize uzrokovane pandemijom COVID-19 su sljedeći (PEMPAL IACOP, 2020., 14-20):

- nejasno koliko dugo će trajati 'zatvaranje svijeta' ili 'karantena', te povezana epidemiološka mjera socijalnog distanciranja

- nepostojanje planova oporavka od katastrofa i kontinuiteta poslovanja na razini funkcija interne revizije, što je značajno utjecalo i utječe na sposobnost prilagođavanja funkcija novonastalim uvjetima rada na daljinu

- neintegriranost informacijskih sustava poduzeća što rezultira poteškoćama prilikom prikupljanja revizijskih dokaza uslijed nepostojanja adekvatnih revizijskih alata, tehnika i metoda, kao i nemogućnošću obavljanja angažmana na daljinu, a prvenstveno angažmana s izražavanjem uvjerenja

- ograničeni revizijski resursi i nedovoljna informatička kompetentnost

- loša informatička povezanost i visoki troškovi prikupljanja podataka

- uvjeravanje upravljačkih struktura o koristima novih načina rada na daljinu, a posebice izvješćivanja o rezultatima angažmana interne revizije.

- Uslijed toga, interni revizori trebaju naučiti lekciju iz svih problema uzrokovanih pandemijom COVID-19 te navedene izazove pretvoriti u prilike za poboljšavanje svog djelovanja u budućnosti, a posebice trebaju (PEMPAL IACOP, 2020., 14-20):

- razmotriti revidiranje postojećeg načina oblikovanja strategija planiranja interne revizije i uvesti promjene u oblikovanje strategija nakon korone (engl. Post-Corona Strategies),

- oblikovati planove oporavka od katastrofa i kontinuiteta poslovanja na razini funkcija interne revizije,

- implementirati pametnije načine rada na daljinu (engl. Smarter Ways of Working) u budućnosti koji imaju pozitivan utjecaj na moral i samopouzdanje članova funkcije interne revizije, kao i na okoliš zbog smanjivanja putovanja,

- razmotriti ulaganje u revizijske programe i informatičku kompetentnost,

- testirati uvođenje inovativnih načina povezivanja s članovima funkcije interne revizije uslijed rada na daljinu koji se mogu koristiti u budućnosti,

- testirati uvođenje novih načina agilnijeg i jasnog izvješćivanja koji se može koristiti u budućnosti. 
Prema tome, može se zaključiti kako je, u suvremenim uvjetima poslovanja, neprihvatljivo da interni revizori ,samo promatraju napore ostalih u poduzeću pri ostvarivanju definiranih stopa rasta i razvoja poduzeća kao uvjeta njegova opstanka. Razvijajući nove pristupe revidiranju i nove revizijske proizvode i usluge, oni se moraju aktivno uključivati i pridonositi ostvarivanju ciljeva poduzeća. Adaptivno ponašanje i permanentna prilagodba funkcije interne revizije utjecajima iz okoline koji ruše temelje na kojima počiva tradicionalna organizacija i upravljanje jest conditio sine qua non njezina daljnjeg razvoja“ (Tušek, 2017., 29).

\section{IZAZOVI EKSTERNE REVIZIJE U RAZDOBLJU PANDEMIJE COVID-19}

Eksterna revizija ima ulogu pružanja razumnog uvjerenja o realnosti i objektivnosti financijskih izvještaja. Primarno je usmjerena eksternim interesno-utjecajnim skupinama, ali značajnu ulogu treba imati i u kontekstu pružanja relevantnih informacija upravljačkim strukturama revidiranog subjekta. Iako su eksterni revizori pravno i strukturno odvojeni od revidiranog subjekta, interakcija između revidiranog subjekta, revizijskog odbora i eksternih revizora neophodna je za prikupljanje relevantnih, transparentnih i pouzdanih revizijskih dokaza. Angažmani eksternih revizora podrazumijevanju fizičko sudjelovanje i komunikaciju s revizijskim odborom i menadžmentom subjekta, kao i aktivnu komunikaciju i suradnju s funkcijom interne revizije, a sve radi prikupljanja dostatnih i primjerenih revizijskih dokaza na kojima će utemeljiti svoje zaključke. Pri tome, dostatnost podrazumijeva mjeru količine dokaza, a primjerenost njihove relevantnosti i pouzdanosti (Međunarodni standard za angažmane s izražavanjem uvjerenja 3000, točka 33.). Jasno je da je kriza uzrokovana pandemijom COVID-19, a koja je rezultirala socijalnom izolacijom, zabranom kontakata, radom na daljinu, ograničenim kretanjem i drugim epidemiološkim mjerama, utjecala na mogućnosti obavljanja revizije financijskih izvještaja i svih postupaka i metodologije koja se primjenjuje u 'normalnim' uvjetima. Kao i u drugim profesijama, i eksterni revizori bili su primorani raditi na daljinu. „Pandemija uzrokovana COVID-om 19 utjecala je na poslovanje subjekata, ali i na sam rad revizora, koji moraju svoje postupke prilagoditi novonastalim okolnostima, što će zasigurno utjecati na potrebu dodatnog angažmana, utrošenih sati, ali i na moguća kašnjenja u odnosu na prvotni plan revizije." (Pretnar Abičić, 2020., 30)

Međunarodni odbor za standarde revidiranja i izražavanja uvjerenja (engl. International Auditing and Assurance Standards Board - IAASB) u ožujku 2020. godine objavljuje prvo priopćenje u vezi s pandemijom COVID-19. Odbor navodi da se revizije neovisno o krizi i dalje trebaju obavljati u skladu s Međunarodnim 
revizijskim standardima, a što može rezultirati različitim i poboljšanim razmatranjima s obzirom na trenutačne okolnosti te će u tome kontekstu revizori možda trebati razviti alternativne postupke kako bi prikupili dostatne i primjerene revizijske dokaze koji će biti potkrepljujući njihovom mišljenju ili mogu rezultirati modifikacijom mišljenja (IAASB, 2020. a). „Nesigurnost i nepredvidivost mogu stvoriti nove ili povećane rizike značajnog pogrešnog prikazivanja. U planiranju revizije, revizori možda nisu predvidjeli te rizike ili su razmatrali identificirane rizike na drugačiji način." (IAASB, 2020. a, 1)

Većina događanja uzrokovanih pandemijom razmatra se u negativnom kontekstu. Međutim, Odbor u svojoj objavi ohrabruje revizore i potiče ih da situaciju iskoriste za pronalaženje i korištenje prilika da stvari rade drugačije, gdje kao primjer navode korištenje novih, ili izmijenjeno korištenje postojećih tehnoloških resursa (IAASB, 2020. a, 1).

Osim modifikacije metodologije obavljanja revizije financijskih izvještaja, revizori u vidu trebaju imati činjenicu da djeluju u izrazito nepredvidivom i promjenjivom okruženju, koje može rezultirati promjenama okvira financijskog izvještavanja, spektra inherentnog rizika, promjenama zakonske regulative, novim procesima obavljanja poslovnih aktivnosti i slično. U tom smislu, Odbor upozorava revizore da posebnu pažnju u revizijskom procesu trebaju usmjeriti na razmatranje politika i procedura kontrole kvalitete (engl. Quality Control Policies and Procedures) u vezi s usmjeravanjem i nadzorom pojedinih timova i provjerom njihova rada, dok na razini angažmana, trebaju povećati svijest o mogućim prijevarama ili pogreškama, uključujući prijevarno financijsko izvještavanje i u tom smislu osnažiti primjenu profesionalnog skepticizma u provođenju revizijskih postupaka (IAASB, 2020. a, 1)

Odgovor Odbora na krizu uzrokovanu pandemijom virusne bolesti COVID-19 uključuje razvoj i objavu publikacija (engl. Staff Alerts) o nekoliko izabranih ključnih područja u vezi primjene Međunarodnih revizijskih standarda u procesu revizije financijskih izvještaja tijekom kriznih uvjeta djelovanja, a kojima je cilj podržati javni interes i ulogu koju revizori imaju u zadržavanju povjerenja u financijsko izvještavanje. Područja koja IAASB u tom smislu smatra posebno značajnim jesu (IAASB):

- revizorovo izvješćivanje (engl. Auditor Reporting)

- vremenska neograničenost poslovanja (engl. Going Concern)

- naknadni događaji (engl. Subsequent Events)

- revizija računovodstvenih procjena (engl. Auditing Accounting Estimates)

- razmatranja za revizije u javnom sektoru (engl. Public Sector Audit Considerations). 
Do lipnja 2020. godine Odbor je objavio tri publikacije. Krajem travnja 2020. godine objavljen je materijal kojim se revizore usmjerava na ključna područja pri razmatranju vremenske neograničenosti poslovanja u razdoblju pandemije. Primjeri događaja ili uvjeta koji mogu nastati uslijed krize uzrokovane pandemijom uključuju gubitak glavnih tržišta, prihoda, manjak radne snage; značajno smanjenje vrijednosti imovine koja stvara novčane tokove kao i kratkotrajne imovine - zaliha; odgode lansiranja novih proizvoda ili usluga; fluktuacije međunarodne razmjene; pitanje vrednovanja; zatim kreditne rizike i pitanje solventnosti (IAASB, 2020. b, 4-7). U smislu dužne profesionalne pažnje u ispunjavanju njihovih odgovornosti po pitanju vremenske neograničenosti poslovanja, revizori trebaju razmotriti primjenu dodatnih ili poboljšanih revizijskih postupaka, koristiti robusnije procedure koje mogu pomoći u donošenju zaključka, a u kontekstu izvješća revizori moraju biti spremni na promjene u dijelu odlomka o vremenskoj neograničenosti poslovanja, ključnih revizijskih pitanja, a i modifikacije samog mišljenja (IAASB, 2020. b, 3). Primjeri dodatnih procedura koje revizori mogu koristiti uključuju analizu prognoziranih novčanih tokova i dobiti s ciljem ocjene pouzdanosti osnovnih ulaznih podataka i adekvatnosti korištenih pretpostavki trendova u izradi planova. Osim toga, revizori mogu ocijeniti izvedivost planova menadžmenta za buduće aktivnosti u vezi s procjenom vremenske neograničenosti poslovanja potvrđivanjem postojanja, zakonitosti i provedivosti dogovora o pružanju ili održavanju financijske potpore u vezi s i trećim stranama kao i ocjenom financijskih sposobnosti za dodatnim financiranjem tih strana, zatim proučavanjem uvjeta financiranja i određivanja jesu li probijeni ugovoreni rokovi, te potvrđivanjem postojanja, uvjeta i adekvatnosti objekta financiranja (IAASB, 2020. b, 8-10). Nadalje, Odbor procjenjuje da će u ovim uvjetima nesigurnosti veći broj revidiranih financijskih izvještaja uključivati proširene objave o događajima ili uvjetima koji mogu izazvati značajnu sumnju u vremensku neograničenost poslovanja.

Nesigurnost i izazovi koje nosi pandemija COVID-19 imaju za posljedicu povećanu vjerojatnost nastanka neplaniranih događaja u bilo kojem trenutku kao i neizvjesnost u procjeni trajanja tih događaja. Rezultat tih okolnosti može biti pomicanje rokova financijskog izvještavanja, a što utječe na reviziju financijskih izvještaja u kontekstu pitanja naknadnih događaja. „Revizori će vrlo vjerojatno usmjeriti veći fokus na događaje koji nastaju između datuma financijskih izvještaja i datuma izvješća neovisnog revizora (tj. naknadnih događaja) i učinaka, ako postoje, tih događaja na financijske izvještaje.“ (IAASB, 2020. c, 1) Ako su u nekim zemljama odobrena produženja rokova predaje financijskih izvještaja, a revizori su već proveli odgovarajuće postupke u vezi s ocjenom naknadnih događaja, revizori će morati provesti dodatne postupke kako bi revizijski dokazi pokrivali cijelo razdoblje do datuma izvješća neovisnog revizora. Primjeri događaja ili uvjeta koji mogu nastati kao rezultat pandemije, i koji mogu biti važni revizoru u ocjeni nastanka naknadnih događaja, su (IAASB, 2020. c, 4): 
- nove obveze, posudbe ili jamstva,

- nedavna ili planirana prodaja ili akvizicija imovine uslijed pandemije,

- povećanje vlastitog kapitala ili izdavanje dužničkih instrumenata, ili dogovor o spajanju ili likvidiranju planiranih aktivnosti,

- isplate pomoći ili poticaja od strane države,

- promjene u vezi s rezerviranjima,

- neuobičajene računovodstvene prilagodbe,

- događaji koji u pitanje dovode primjerenost korištenih računovodstvenih politika u financijskim izvještajima,

- događaji važni za mjerenje procjena ili rezerviranja u financijskim izvještajima,

- događaji važni za mogućnosti nadoknade imovine,

- modifikacija postojećih ugovornih aranžmana,

- porezna razmatranja,

- otpremnine zaposlenima zbog prekida radnog odnosa i smanjenja broja zaposlenih.

Kriza uzrokovana SARS-CoV-2 virusom zasigurno rezultira prosudbama menadžmenta u mjeri većoj od uobičajene, čime se podrazumijeva povećana razina profesionalne prosudbe revizora pri čemu se još snažnije mora voditi profesionalnim skepticizmom u ocjeni naknadnih događaja. Primjena profesionalnog skepticizma u vezi s naknadnim događajima znači propitkivanja i razmatranja dostatnosti i primjerenosti revizijskih dokaza koji će osigurati da su svi naknadni događaji identificirani i da su na odgovarajući način iskazani u financijskim izvještajima subjekta (prilagodba iznosa u financijskim izvještajima ili odgovarajuća objava o prirodi i procjena financijskog učinka naknadnog događaja) (IAASB, 2020. c, 5). U kontekstu revizorova razumijevanja promjena koje su provedene kao odgovor na promjenjivu okolinu, IAASB naglašava da komunikacija s onima odgovornima za upravljanje može biti od velike pomoći pri izboru procedura koje će revizor koristiti za prikupljanje dostatnih i primjerenih revizijskih dokaza.

Utjecaj krize uzrokovane pandemijom COVID-19 na revizorovo izvješćivanje ogleda se u modifikaciji mišljenja neovisnog revizora do koje može doći zbog novih okolnosti poslovanja, ali i novih uvjeta u kojima se obavlja revizijski proces (npr. nemogućnost prikupljanja odgovarajućih revizijskih dokaza), značajnoj neizvjesnosti u pogledu vremenske neograničenosti poslovanja, uključivanju odlomaka ključnih revizijskih pitanja i/ili odlomka isticanja pitanja. U neizvjesnim uvjetima poslovanja korisnici financijskih izvještaja imaju veća očekivanja od revizije financijskih izvještaja. Smanjenju jaza očekivanja značajno mogu pridonijeti transparentne objave u vezi sa značajnim učincima pandemije COVID-19, a koje mogu biti usmjerene na utjecaj volatilnosti financijskih tržišta, kreditnih 
uvjeta ili likvidnosti, intervencije vlade ili promjene proizašle iz smanjene proizvodnje, restrukturiranja i slično (IAASB, 2020. d, 2). Problematika u razdoblju 'karantene' (engl. Lockdown) uključuje pitanje mogućnosti pribavljanja dostatnih i primjerenih revizijskih dokaza (MRevS 330). Pored toga, na mišljenje neovisnog revizora utječu i neispravljena pogrešna prikazivanja koja su značajna na razini tvrdnje ili razini financijskih izvještaja (MRevS 450). U trenutačnim okolnostima na modifikaciju mišljenja neovisnog revizora zbog značajnih pogrešnih prikaza u financijskim izvještajima mogu utjecati prikladnost objava u financijskim izvještajima i odgovarajuća primjena računovodstvenih politika (IAASB, 2020. d, 3).

Zaključno se može istaknuti da su pred eksternim revizorima višestruki izazovi koji se s jedne strane ogledaju u nužnosti modifikacije primjenjivih revizijskih procedura, ubrzane digitalizacije i povećanja obujma ispitivanja te s druge, značajnijoj primjeni profesionalne prosudbe i skepticizma radi stjecanja razumnog uvjerenja o realnosti i objektivnosti temeljnih financijskih izvještaja.

\section{SLIČNOSTI I RAZLIKE ODGOVORA REVIZIJSKE PROFESIJE NA PANDEMIJU COVID-19}

U tablici 1. prikazane su sličnosti i razlike između izazova djelovanja internih i eksternih revizora kao posljedica krize uzrokovane pandemijom COVID-19.

Tablica 1: Sličnosti i razlike između izazova djelovanja internih i eksternih revizora kao posljedica krize uzrokovane pandemijom COVID-19

\begin{tabular}{|c|c|c|}
\hline Kriteriji & INTERNI REVIZORI & EKSTERNI REVIZORI \\
\hline \multirow[b]{3}{*}{$\begin{array}{l}\text { Objekt } \\
\text { revizije }\end{array}$} & $\begin{array}{l}\text { Izloženost novim i do sada nepozna- } \\
\text { tim rizicima poslovanja i povećana } \\
\text { vjerojatnost rizika prijevare. }\end{array}$ & $\begin{array}{l}\text { Značajno proširen spektar inheren- } \\
\text { tnih rizika što rezultira višim rizikom } \\
\text { pogrešnog prikazivanja. }\end{array}$ \\
\hline & $\begin{array}{l}\text { Neplanirana i nesustavna implemen- } \\
\text { tacija informacijsko-komunikacijske } \\
\text { tehnologije, kao i rad na daljinu re- } \\
\text { zultira manjkavostima u kontrolnim } \\
\text { procesima. }\end{array}$ & $\begin{array}{l}\text { Opsežnije provođenje testova kon- } \\
\text { trola radi procjene kontrolnog rizika. }\end{array}$ \\
\hline & $\begin{array}{l}\text { Promjene u poslovanju u pogledu } \\
\text { smanjenog obujma poslovanja, sma- } \\
\text { njene likvidnosti, dodatnog zaduži- } \\
\text { vanja te neplaniranih događaja rezul- } \\
\text { tiraju nužnošću ažuriranja strateških, } \\
\text { godišnjih i pojedinačnih planova u } \\
\text { pogledu usmjeravanja pozornosti na } \\
\text { nova ključna područja poslovanja } \\
\text { poduzeća. }\end{array}$ & $\begin{array}{l}\text { Promjene u poslovanju u pogle- } \\
\text { du smanjenog obujma poslovanja, } \\
\text { smanjene likvidnosti, dodatnog za- } \\
\text { duživanja te neplaniranih događaja, } \\
\text { rezultiraju isticanjem dodatnih ključ- } \\
\text { nih revizijskih pitanja u izvješću ne- } \\
\text { ovisnog revizora, ocjeni vremenske } \\
\text { neograničenosti poslovanja i poseb- } \\
\text { nom usmjerenošću reviziji računo- } \\
\text { vodstvenih procjena. }\end{array}$ \\
\hline
\end{tabular}




\begin{tabular}{|c|c|c|}
\hline $\begin{array}{l}\text { Predmet } \\
\text { revizije }\end{array}$ & $\begin{array}{l}\text { Uvažavanje promjena te poznavanje } \\
\text { i razumijevanje kriterija za ocjenu. }\end{array}$ & $\begin{array}{l}\text { Uvažavanje promjena te poznavanje } \\
\text { i razumijevanje kriterija za ocjenu. }\end{array}$ \\
\hline $\begin{array}{l}\text { Kriteriji } \\
\text { zа осјепи }\end{array}$ & $\begin{array}{l}\text { Modifikacija ciljeva poslovanja po- } \\
\text { duzeća u pogledu prevladavanja kri- } \\
\text { znog razdoblja i oblikovanje strate- } \\
\text { gije poslovanja koja će osigurati vre- } \\
\text { mensku neograničenost poslovanja. } \\
\text { Zakonska regulativa u pogledu dr- } \\
\text { žavne pomoći, olakšica i poreznih } \\
\text { rasterećenja. }\end{array}$ & $\begin{array}{l}\text { Pomicanje rokova financijskog iz- } \\
\text { vještavanja utječe na reviziju finan- } \\
\text { cijskih izvještaja u kontekstu pitanja } \\
\text { naknadnih događaja. } \\
\text { Državne pomoći, olakšice i porezna } \\
\text { rasterećenja imaju značajan utjecaj } \\
\text { na financijski položaj i uspješnost } \\
\text { poslovanja. }\end{array}$ \\
\hline $\begin{array}{l}\text { Postupak } \\
\text { ocjene }\end{array}$ & $\begin{array}{l}\text { Rad na daljinu, uz neizostavnu pri- } \\
\text { mjenu informacijsko-komunika- } \\
\text { cijske tehnologije, zahtijeva modi- } \\
\text { fikaciju revizijske metodologije i } \\
\text { primjenu naprednih tehnika analize } \\
\text { podataka. } \\
\text { Ograničenja u tom pogledu mogu } \\
\text { biti neadekvatna razina tehnološkog } \\
\text { razvoja poduzeća kao i neodgovara- } \\
\text { juće kompetencije internih revizora } \\
\text { za primjenu tehnologije. }\end{array}$ & $\begin{array}{l}\text { Izazovi u uspostavljanju kvalitetne } \\
\text { komunikacije s klijentom na daljinu. } \\
\text { Rad na daljinu, uz neizostavnu pri- } \\
\text { mjenu informacijsko-komunika- } \\
\text { cijske tehnologije, zahtijeva modi- } \\
\text { fikaciju revizijske metodologije i } \\
\text { primjenu naprednih tehnika analize } \\
\text { podataka. } \\
\text { Ograničenja u tom pogledu mogu } \\
\text { biti neadekvatna razina tehnološkog } \\
\text { razvoja poduzeća kao i neodgovara- } \\
\text { juće kompetencije eksternih revizora } \\
\text { za primjenu tehnologije. }\end{array}$ \\
\hline Korisnici & Nema promjena & Nema promjena \\
\hline
\end{tabular}

Izvor: izrada autora.

U razdoblju pandemije COVID-19 interni i eksterni revizori suočavaju se brojnim, do nedavno i nepoznatim izazovima. Iako su i interni i eksterni revizori, gotovo preko noći, suočeni s nemogućnosti normalnog i uobičajenog obavljanja svakodnevnih aktivnosti uvođenjem rada na daljinu, za eksterne revizore koji kod pojedinih klijenata prvi put obavljaju reviziju financijskih izvještaja taj izazov je naglašeniji. Prikupljanje podataka i komunikacija mrežnim putem izazivaju nelagodu i suzdržanost i kada je u pitanju interna revizija, a posebice u slučaju prve godine angažmana eksterne revizije. Radom na daljinu je dodatno otežana interakcija s klijentom, upoznavanje njegova poslovanja i mogućnost pristupanja neophodnim podacima. U ovoj situaciji posebno dolazi do izražaja značaj revizijskog odbora kao svojevrsnog posrednika, odnosno moderatora između revizorskog društva i klijenta, kao i važnost suradnje eksternih revizora s internim revizorima kao kvalitetnog izvora relevantnih informacija o važnim poslovnim procesima, manjkavostima u sustavu internih kontrola i najvažnijih poslovnih rizika kao inputa za procjenu inherentnog i kontrolnog rizika. S druge strane, interni revizori su suočeni s povećanim zahtjevima za savjetodavnim angažmanima i angažmanima na zahtjev, kao i značajnim promjenama u poslovnim procesima koji rezultiraju do tada nepostojećim rizicima, a što rezultira nužnošću za ažuriranjem i značajnim promjenama u strateškim, godišnjim, pa i pojedinačnim planovima interne revizije. 
Izazovi koji su zajednički i internim i eksternim revizorima odnose se na neophodne modifikacije korištene metodologije u fazama planiranja i obavljanja revizijskih angažmana u kontekstu procjene revizijskih rizika i postupaka za prikupljanje revizijskih dokaza. Više nego ikada ranije, revizori moraju imati vještine prilagođavanja radu na daljinu i korištenja informacijsko-komunikacijske tehnologije, fleksibilnost u primjeni različitih tehnika prikupljanja revizijskih dokaza $\mathrm{s}$ naglaskom na napredne tehnike analize podataka, proaktivnost u komunikaciji sa svim razinama upravljanja kao i s revizijskim odborom. Revizori moraju imati neophodna znanja i vještine primjene recentnih trendova razvoja revizijske profesije te moraju agilno reagirati na novonastale okolnosti i promjene u operativnim procesima poslovanja poduzeća koje su rezultirale novim rizicima. Međutim, tek s određenim vremenskim odmakom, nakon završetka kriznog razdoblja, moći će se preciznije sagledati najznačajnijih slabosti i koristi ubrzane digitalizacije, kao i trend razvoja suradnje između internih i eksternih revizora.

\section{ZAKLJUČAK}

Suvremeno doba obilježava krizni način poslovanja poduzeća, kao i djelovanja interne i eksterne revizije. Interna i eksterna revizija, kao vrlo važni nadzorni mehanizmi korporativnog upravljanja, značajno su pogođene krizom koju je uzrokovala pandemija COVID-19. Da bi revizijska profesija mogla iskoristiti navedenu krizu kao šansu, odnosno priliku, važno je da se interni i eksterni revizori proaktivno i agilno prilagođavaju novonastalim okolnostima, i na taj način doprinose poboljšavanju procesa korporativnog upravljanja, upravljanja rizicima i sustava internih kontrola.

Interni i eksterni revizori u razdoblju pandemije COVID-19 suočeni su s iznenadnim, neplaniranim, i do sada nepostojećim rizicima poslovanja koje moraju uvažiti u provođenju revizijskih angažmana, što je u najvećoj mjeri rezultiralo promjenama godišnjih, pa i strateških planova internih revizora, odnosno faze planiranja pojedinog revizijskog angažmana i kod internih i kod eksternih revizora. I interni i eksterni revizori suočavaju se s istim izazovima u poslovanju poduzeća, te gospodarskom i političkom okruženju, ali promatrano s aspekta objekta revizije, svatko se s tim izazovima suočava u skladu sa specifičnim ciljevima profesije interne ili eksterne revizije. Unatoč razlikama, nedvojbeno je da u korištenoj metodologiji internih i eksternih revizora postoje brojna podudaranja, a koja su najočitija u pogledu korištene metodologije prikupljanja revizijskih dokaza gdje, i u razdoblju prije pandemije COVID-19, tehnike analize podataka imaju sve veću važnost. Pored toga, razdoblje neplanirane i ubrzane digitalizacije i interni i eksterni revizori trebaju iskoristiti kao priliku za produbljivanje suradnje i pronalaženje koristi te suradnje, koja bi u svakom slučaju trebala rezultirati uštedom vremenskih, ljudskih i financijskih resursa uz uvažavanje temeljnog načela neovisnosti i objektivnosti. 


\section{LITERATURA}

1. AuditBoard, (2020.), COVID-19 Response Strategy: Evolving Internal Audit Practices for Success, AuditBoard, dostupno na: https://dl.theiia.org/Documents/COVID-19-Response-Strategy-Internal-Audit-Practices.pdf [pristupljeno 26.5.2020.]

2. Hrvatski institut internih revizora, (2017.), Međunarodni okvir profesionalnog djelovanja (MOPD) - prijevod s engleskog jezika, The Institute of Internal Auditors Global \& Hrvatski institut internih revizora, Republika Hrvatska, Zagreb.

3. IAASB, dostupno na: www.iaasb.org [pristupljeno 26.5.2020.]

4. IAASB, (2020. a), Staff Audit Practice Alert - Highlighting Areas of Focus in an Evolving Audit Environment Due to the Impact of COVID-19, ožujak 2020., dostupno na: https://www.ifac.org/system/files/uploads/IAASB/ Staff $\% 20$ Alert $\% 20$ - $\% 20$ Audit $\% 20$ Considerations $\% 20$ Arising $\% 20$ from $\% 20$ Changes\%20Due\%20to\%20Coronavirus.pdf [pristupljeno 26.5.2020.]

5. IAASB, (2020. b), Staff Audit Practice Alert - Going Concern in the Current Evolving Environment - Audit Considerations for the Impact of COVID-19, travanj 2020., dostupno na: https://www.iaasb.org/publications/staff-audit-practice-alert-going-concern [pristupljeno 26.5.2020.]

6. IAASB, (2020. c), Staff Audit Practice Alert - Subsequent Events in the Current Evolving Environment-Audit Considerations for the Impact of COVID-19, svibanj 2020., dostupno na: https:/www.iaasb.org/publications/ subsequent-events-current-evolving-environment-audit-considerations-impact-covid-19 [pristupljeno 26.5.2020.]

7. IAASB, (2020. d), Staff Audit Practice Alert - Auditor Reporting in the Current Evolving Environment Due to COVID-19, svibanj 2020., dostupno na: https://www.iaasb.org/publications/auditor-reporting-current-evolving-environment-due-covid-19 [pristupljeno 26.5.2020.]

8. KPMG, (2020. a), COVID-19: Role of Internal Audit Leaders, KPMG AG, Switzerland, dostupno na: https://assets.kpmg/content/dam/kpmg/ch/pdf/covid19-role-of-internal-audit-leaders.pdf [pristupljeno 26.5.2020.]

9. KPMG, (2020. b), Impact of the COVID-19 Crisis on Internal Audit Functions of Financial Institutions, KPMG Advisory N.V., Netherlands, dostupno na: https://assets.kpmg/content/dam/kpmg/cy/pdf/2020/04/impact-of-the-covid-19-crisis-on-internal-audit-functions-of-financial-institutions.pdf [pristupljeno 26.5.2020.]

10. Međunarodni odbor za standarde revidiranja i izražavanja uvjerenja, (n.d.), dostupno na: www.iaasb.org [pristupljeno 27.5.2020.] 
11. PEMPAL IACOP, (2020), The Impact of COVID-19 on the Role and Activities of Internal Audit, PEMPAL Internal Audit Community of Practice (IACOP), dostupno na: https://www.pempal.org/sites/pempal/files/IACOP/ covid_publication_pages_pdf [pristupljeno 8.7.2020.]

12. Pretnar Abičić, S., (2020.), Utjecaj COVID-19 na reviziju financijskih izvještaja, Računovodstvo i financije, LXVI (5), str. 28-30.

13. The IIA's Audit Executive Center, (2020.), COVID-19: Longer-Term Impact on Internal Audit, Audit Executive Center Knowledge Brief, The AEC \& The IIA, USA, Florida, Lake Mary, dostupno na: https://dl.theiia.org/Documents/COVID-19-Longer-Term-Impact-on-Internal-Audit.pdf [pristupljeno 8.7.2020.]

14. The Institute of Internal Auditors Global, (2020.), Internal Audit in the COVID-19 Era: A Global Glance at Responses to the Pandemic, The IIA Global, USA, Florida, Lake Mary, dostupno na: https://na.theiia.org/periodicals/Public\%20Documents/Internal-Audit-in-the-COVID-19-Era.pdf [pristupljeno 8.7.2020.]

15. Tušek, B., Žager, L., Barišić, I., (2014.), Interna revizija, Hrvatska zajednica računovođa i financijskih djelatnika, Republika Hrvatska, Zagreb.

16. Tušek, B., (2017.), Interna revizija - organizacijski i metodološki aspekti, TEB Poslovno savjetovanje d.o.o., Republika Hrvatska, Zagreb.

17. Tušek, B., Ježovita, A., Halar, P., (2018.), Perspektive razvoja i izazovi funkcije interne revizije $u$ eri digitalne transformacije poslovanja, Zbornik radova Ekonomskog fakulteta Sveučilišta u Mostaru, Bosna i Hercegovina, Mostar, XXIV., str. 258-289, dostupno na: https://hrcak.srce.hr/216718 [pristupljeno 26.5.2020.] 


\title{
Boris Tušek, PhD
}

Faculty of Economics \& Business, University of Zagreb, Zagreb, Republic of Croatia btusek@efzg.hr

\section{Ana Ježovita, PhD}

Faculty of Economics \& Business, University of Zagreb, Zagreb, Republic of Croatia ajezovita@efzg.hr

\section{Petra Halar, MA}

Faculty of Economics \& Business, University of Zagreb, Zagreb, Republic of Croatia phalar@efzg.hr

\section{CHALLENGES OF INTERNAL AND EXTERNAL AUDIT IN THE ERA OF THE COVID-19 PANDEMIC}

Received: August 21, 2020

Abstract: December 2, 2020

https://doi.org/10.46458/27121097.2020.26.111

Review

\begin{abstract}
The crisis caused by the respiratory disease COVID-19 has changed and is fundamentally changing private and business world, what is supported by the fact that in the future it will be talked about the world 'before' and 'after' the COVID-19 pandemic. COVID-19 is a disruption that irreversibly changes the internal and external environment of companies, regardless of their size, activity or country in which they operate. As it has been confirmed several times throughout the history, in times of crisis the importance of effective and efficient internal and external corporate governance oversight mechanisms, that make a difference and contribute to the companies' performance, is confirmed and necessity of their existence is emphasized, whereas internal and external audit represent the key mechanisms. Therefore, the modern era poses numerous new challenges to internal and external auditing or, in other words, to the entire audit profession, which must operate more proactively by anticipating all the possible scenarios of the disruptive events' impact on companies' business and propose tailored solutions for each situation. The impact of the pandemic caused by the respiratory disease COVID-19 on internal and external auditing is twofold. On the one
\end{abstract}


hand, the companies' business that represents the object of the audit engagements is changing, while on the other hand, the operating mode of internal and external auditing is changing also. In order for the audit profession to add value and improve the company's business by providing timely and proactive audit and non-audit engagements, it is primarily important that internal and external audit adapt to contemporary business conditions and new challenges they are facing in their activities. In the conditions of 'remote auditing', especially the importance of integrated auditing, or joint cooperation between internal and external audit in order to overcome all challenges and shortcomings in the activities of either internal or external auditors, is emphasized. This ensures the synergy of internal and external corporate governance oversight mechanism that ultimately leads to company's survival and adds value to its stakeholders in contemporary, extremely uncertain business conditions caused by the COVID-19 pandemic.

This paper seeks to provide answers to the following research questions: What challenges faces the audit profession in the era of pandemic caused by the respiratory disease COVID-19? How do these challenges affect the internal and external auditing? How should internal and external audit respond to growing challenges in order to fulfil their purpose of existence? In order to answer the research questions, the objectives of the paper are defined: 1) to give an overview of the impacts of the COVID-19 pandemic on the internal and external auditing, 2) to analyse and suggest possible responses of internal and external audit to the growing challenges they face in their activities due to the COVID-19 pandemic, 3) to analyse and identify opportunities for joint cooperation between internal and external audit in order to increase their significance as corporate governance oversight mechanisms in the COVID-19 pandemic era. In order to achieve the objectives of this paper, the analysis of secondary data was performed, by using primarily scientific methods of analysis, synthesis, description, classification and comparison.

Keywords: internal audit, external audit, COVID-19;

JEL: M41, M42 